INTIQAD: JURNAL AGAMA DAN PENDIDIKAN ISLAM

ISSN 1979-9950 (print) || ISSN 2598-0033 (online), http://jurnal.umsu.ac.id/index.php/intiqad DOI: 10.30596/intiqad.v13i2.7473

Vol. 13, No. 2 (December 2021)

\title{
Pengetahuan dan Pengamalan Thaharah Siswa dalam Menjaga Kebersihan dan Kesehatan Era Pandemi Covid-19 di Madrasah
}

\author{
Nur Ainun Nasution ${ }^{1 *}$, Sita Ratnaningsih ${ }^{2}$, Romlah Abubakar Askar ${ }^{3}$ \\ Universitas Islam Negeri Syarif Hidayatullah Jakarta*1,2,3 \\ "1email:nur_nasution19@mhs.uinjkt.ac.id \\ 2email: sita@uinjkt.ac.id \\ 3 email: romlah.askar@uinjkt.ac.id
}

\begin{tabular}{|c|c|}
\hline Abstract & Artikel Info \\
\hline $\begin{array}{l}\text { The practice of taharah requires Muslims to prevent the } \\
\text { transmission of Covid-19. This study aims to analyze the } \\
\text { knowledge and practice of students' taharah in the Covid-19 } \\
\text { pandemic era. The method used is descriptive qualitative. } \\
\text { Among the students' knowledge is knowing the meaning of } \\
\text { thaharah (istinja', ablution, tayamum), taharah procedures, } \\
\text { thaharah etiquette, thaharah law, sunnah-sunnah thaharah } \\
\text { and the meaning of thaharah in a broad sense by maintaining } \\
\text { cleanliness and health, especially in the era of the Covid-19 } \\
\text { pandemic. . The practice of thaharah for students in the era } \\
\text { of the covid- } 19 \text { pandemic, such as routinely brushing their } \\
\text { teeth and ablution before going to bed, a small number of } \\
\text { students performing ablution outside prayer times, } \\
\text { regularizing clean Fridays, cutting nails every Friday and } \\
\text { maintaining cleanliness and health through the practice of } \\
\text { thaharah. . Islam considers cleanliness as a civilization and } \\
\text { worship. Therefore, cleanliness is part of the daily life of a } \\
\text { Muslim. }\end{array}$ & $\begin{array}{c}\text { Received: } \\
\text { 03 September } \\
\text { Revised: } \\
\text { 07 October } 2021 \\
\text { Accepted: } \\
\text { 27 November } 2021 \\
\text { Published: } \\
\text { 04 December 2021 }\end{array}$ \\
\hline Keywords $\quad$ : Knowledge, Practice, Thaharah & \\
\hline \multicolumn{2}{|l|}{ Abstrak } \\
\hline $\begin{array}{l}\text { Pengamalan thaharah menuntut kaum muslim untuk } \\
\text { mencegah penularan Covid-19. Penelitian ini bertujuan } \\
\text { untuk menganalisis pengetahuan dan pengamalan thaharah } \\
\text { siswa era pandemi Covid-19. Metode yang digunakan } \\
\text { kualitatif deskriptif. Diantara pengetahuan siswa adalah } \\
\text { mengetahui makna thaharah (istinja', wudhu, tayamum), tata } \\
\text { cara thaharah, adab-adab thaharah, hukum thaharah, sunnah- } \\
\text { sunnah thaharah dan makna thaharah dalam arti luas dengan } \\
\text { menjaga kebersihan dan kesehatan terutama di era pandemi } \\
\text { Covid-19. Pengamalan thaharah siswa di era pandemi covid- }\end{array}$ & \\
\hline
\end{tabular}


19 seperti merutinkan sikat gigi dan wudhu sebelum tidur, sebagian kecil siswa berwudhu di luar waktu-waktu shalat, merutinkan Jum'at bersih, memotong kuku setiap hari Jum'at dan menjaga kebersihan dan kesehatan melalui pengamalan thaharah. Islam menganggap kebersihan sebagai suatu peradaban dan ibadah. Oleh karena itu kebersihan menjadi bagian dari kehidupan sehari-hari seorang muslim.

Kata Kunci : Pengetahuan, Pengamalan, Thaharah.

\section{A. Pendahuluan}

Belakangan ini, publik dunia dipenuhi dengan pemberitaan tentang penyebaran virus Corona. Awalnya wabah ini diumumkan pada tanggal 31 Desember 2019 (Yuliana, 2020). Virus ini sangat kecil dan berbentuk bulat dengan diameter sekitar $125 \mathrm{~nm}$ sehingga sulit untuk dideteksi (Parwanto, 2020). Berdasarkan data terbaru di dunia, dari data Worldometers per Selasa, 27 Juli 2021, Indonesia masih berada di posisi pertama sebagai negara dengan kasus kematian tertinggi di dunia (Marga, 2021).

Pemerintah dan ahli kesehatan menghimbau masyarakat untuk menerapkan protokol kesehatan diantaranya, cara mencuci tangan yang baik, memakai masker setiap keluar rumah, menjaga jarak dengan orang lain, mengurangi mobilitas dan sebagainya (Yunus dan Rezki, 2020). Dengan beragam protokol kesehatan tersebut banyak dari kalangan umat Islam yang sampai lupa bahwa dalam Islam sudah ada solusinya bahkan sudah dipraktekkan setiap hari yaitu Protokol Thaharah.

Thaharah memiliki kedudukan yang sangat penting dalam syari'at Islam, thaharah membedakan antara Islam dengan agama lain. Agama-agama selain Islam tidak mempunyai perhatian yang sangat tinggi dan agung yang melebihi agama Islam dalam hal kebersihan. Kebersihan dalam Islam diajarkan mulai dari bangun tidur sampai tidur kembali, disinilah letak ketinggian ajaran agama Islam (Nurhayati dkk, 2020).

Menjaga kebersihan terkait kepentingan orang banyak merupakan bagian dari perintah agama, dengan menjaga kebersihan terutama anggota badan yang terbuka dan aktif melakukan kegiatan akan mencegah kuman dan kotoran (Nurdin, 2020). Kebersihan 
harus harus menjadi sebuah nilai, karakter, budaya dan identitas bagi kaum muslim, sehingga kebersihan dipandang sebagai ciri khas setiap muslim. Sama halnya seperti muslim yang senantiasa memakai baju koko, kopiyah, sarung sehingga pakaian ini dikenal sebagai ciri khas seorang muslim dalam hal pakaian. Maka ciri khas muslim lainnya adalah senantiasa menjaga kebersihan baik kebersihan diri maupun kebersihan lingkungannya (Kudori, 2015).

Di madrasah salah satu pelajaran agama yang diajarkan adalah pelajaran fiqih materi thaharah. Namun pengamalan thaharah di MI Plus Al Muhajirin belum merata. Seperti halnya pengamalan thaharah belum masuk ke toilet, kamar mandi dan tempat wudhu. Begitu juga jumlah WC siswa yang tidak sesuai dengan jumlah siswa. Kamar mandi, toilet dan tempat wudhu merupakan tempat yang seharusnya mejadi pusat perhatian warga Madrasah dalam hal kebersihan karena tempattempat tersebut sering dikunjungi warga madrasah.

Oleh karena itu penulis mengadakan penelitian untuk menganalisis bagaimana pengetahuan dan pengamalan thaharah siswa dalam menjaga kebersihan dan kesehatan pada pembelajaran fiqih era pandemi Covid19 di MI Plus Al Muhajirin Depok Jaya, dengan harapan agar pengamalan thaharah dijadikan sebagai salah satu solusi pencegahan penularan Covid-19 khususnya warga MI Plus Al Muhajirin Depok Jaya.

\section{B. Metode Penelitian}

Penelitian ini menggunakan pendekatan kualitatif terhadap data primer dan data skunder. Jenis penelitian ini sifatnya deskriptif, maksudnya ialah untuk menggambarkan data dari informasi yang berdasarkan fakta yang diperoleh di lapangan. Penelitian deskriptif mengkaji perubahan, bentuk, aktivitas, kesamaan dan perbedaan dengan kejadian lain (Sukmadinata, 2005).

Pada proses penelitian ini dilakukan dengan observasi, wawancara dan dokumentasi. Wawancara ini dilakukan pada tanggal 19, 20 dan 22 Januari 2020 dengan kepala Madrasah, guru fiqih kelas III dan 20 siswa kelas III.

C. Hasil dan Pembahasan

1. Analis Pengetahuan Thaharah Siswa 
INTIQAD: JURNAL AGAMA DAN PENDIDIKAN ISLAM

ISSN 1979-9950 (print) || ISSN 2598-0033 (online), http://jurnal.umsu.ac.id/index.php/intiqad

DOI: 10.30596/intiqad.v13i2.7473

Vol. 13, No. 2 (December 2021)

Dalam Taksonomi Bloom

pengetahuan adalah kemampuan

seseorang untuk mengingat-ingat

kembali atau mengenali tentang nama, rumus, istilah dan ide tanpa mengharapkan kemampuan untuk menggunakannya. (Rustaman dan Nuryani, 2005) Pengetahuan thaharah yang dimiliki siswa akan menuntun dan memudahkan mereka dalam pengamalan thaharah.

Penulis akan memaparkan hasil penelitian mengenai pengetahuan thaharah siswa dalam Pembelajaran Fiqih Era Pandemi Covid-19 di MI Plus Al Muhajirin Depok Jaya.

Dari 20 siswa yang diwawancara, mereka menjawab pertanyaanpertanyaan wawancara mengenai, istinja', wudhu, tayamum, Dan sebagian mereka dapat melafazkan do'a do'a yang berkaitan dengan thaharah seperti do'a masuk keluar kamar mandi, dan do'a selesai berwudhu, niat wudhu. Siswa kelas III juga mengetahui bahwa sangat penting menjaga kebersihan dan kesehatan terutama di era pandemi Covid-19 sekarang, karena menjaga kebersihan dalam Islam sebagai pengamalan thaharah dan tanda keimanan seorang muslim (Wawancara, 2021).

Secara bahasa istinja' adalah perbuatan yang dilakukan untuk menghilangkan najis. Adapun menurut istilah syara' istinja' adalah perbuatan yang dilakukan untuk menghilangkan najis dengan menggunakan benda seperti air dan batu. (Az-Zuhaili, 2011:283)

Menurut bahasa, kata wudhu dengan membaca dhammah pada huruf wawu (wudhu') adalah nama satu perbuatan yang memanfaatkan air dan digunakan untuk membersikan anggotaanggota badan tertentu. Jika kata wudhu dibaca dengan fathah pada huruf wawu (wadhu') ia berarti air yang digunakan untuk berwudhu . Wudhu menurut istilah syara' adalah perbuatan-perbuatan tertentu yang dimulai dengan niat khusus, perbuatan tersebut ialah membasuh muka, kedua tangan, mengusap kepala dan membasuh dua kaki (Al-Hanafi, 2005).

Tayamum adalah mengusap muka dan dua tangan dengan menggunakan debu dari tanah yang suci sebagai media untuk pengganti wudhu dan mandi pada waktu-waktu tertentu. Dengan kata lain Islam memberikan keringanan bagi seorang muslim yang tidak dapat 
INTIQAD: JURNAL AGAMA DAN PENDIDIKAN ISLAM

ISSN 1979-9950 (print) || ISSN 2598-0033 (online), http://jurnal.umsu.ac.id/index.php/intiqad DOI: 10.30596/intiqad.v13i2.7473

Vol. 13, No. 2 (December 2021) berwudhu dengan air disebabkan beberapa udzur tertentu (Qotadah, 2020)

Usia sekolah adalah usia emas untuk menanamkan nilai-nilai hidup bersih dan sehat, karena mereka yang akan menjadi agen perubahan di masa depan, baik pembawa perubahan dalam keluarga, sekolah dan masyarakat (Susanto dkk, 2016)

Yang menjadi masalah kesehatan di Indonesia, termasuk cacingan, diare, sakit gigi, gizi buruk dan penularan virus dan sebagainya muncul karena kekurangan perilaku Program Hidup Bersih dan Sehat (PHBS), sehingga menyebabkan status kesehatan dan kualitas hidup tidak baik (Koem dkk, 2015).

\section{Pengamalan Thaharah Siswa}

Menjaga Kebersihan dan Kesehatan

a. Merutinkan Sikat Gigi dan Berwudhu Sebelum Tidur

Pengamalan diartikan sejauh mana tingkatan seorang muslim berprilaku yang dilandasi oleh syariat dalam agamanya dan bagaimana seseorang berinteraksi dengan dunianya juga dengan manusia lain (Djamaluddin, 1995)
Dalam teori Taksonomi Bloom pengamalan masuk pada ranah psikomotorik. Ranah psikomotorik dapat ditinjau melalui aspek keterampilan peserta didik, yang merupakan pengamalan dari Kegiatan Belajar Mengajar di kelas. Siswa tidak cukup hanya menghapal suatu teori yang sifatnya abstrak ke dalam aktualisasi nyata. Hal ini menjadi sebuah tolok ukur, dapat dipahami atau tidaknya sebuah ilmu secara komprehensif oleh siswa. Siswa yang mengetahui suatu ilmu dengan komprehensif memiliki daya pengamalan yang kuat dalam menerapkan ilmu yang dimilikinya. (Kusnawa, 2012)

Merutinkan sikat gigi dan berwudhu sebelum tidur merupakan bagian ibadah harian siswa yang sudah dirutinkan sejak lama di MI Plus Al Muhajirin Depok Jaya jauh sebelum adanya pandemi Covid-19 dan berlanjut sampai sekarang. Lembaran ibadah harian tersebut diberikan / dikirim ke wali kelas masing-masing siswa setiap bulannya (tanggal 1) setelah diparaf oleh orang tua kemudian 
INTIQAD: JURNAL AGAMA DAN PENDIDIKAN ISLAM

ISSN 1979-9950 (print) || ISSN 2598-0033 (online), http://jurnal.umsu.ac.id/index.php/intiqad

DOI: 10.30596/intiqad.v13i2.7473

Vol. 13, No. 2 (December 2021)

akan dinilai oleh wali kelas masing-masing (Wawancara dan observasi siswa kelas III, 2020).

Berwudhu ketika hendak tidur merupakan bagian sunnah yang dicontohkan Rasulullah shallallahu 'alaihi wasallam, berdasarkan sebuah hadits di bawah ini:

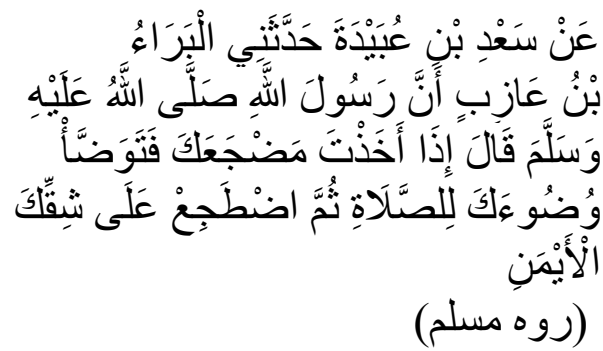

Artinya: "Apabila kamu hendak tidur, maka berwudhulah sebagaimana kamu berwudhu untuk shalat. Setelah itu berbaringlah dengan miring ke kanan," (H.R Muslim).

Hadis ini diriwayatkan oleh Muslim dalam kitab Shahih Muslim, bab do'a ketika akan tidur, nomor hadis 4884 .

Wudhu seorang muslim akan memancarkan cahaya kelak di Padang Mahsyar dan wudhu akan membedakan umat Nabi Muhammad Saw dengan Umat lain, disamping itu wajah yang sering dibasahi air wudhu akan membentuk aura positif diwajah seorang muslim. Segala sesuatu yang Allah perintahkan baik melalui Al-Quran dan sunnah Rasulullah Saw bukanlah untuk mempersulit melainkan untuk kebaikan. (Yasin, 2012)

\section{b. Berwudhu di luar waktu- waktu shalat}

Berdasarkan hasil wawancara dengan 20 siswa MI Plus Al Muhajirin Depok Jaya khususnya kelas III sebagian siswa sudah mulai membiasakan berwudhu diluar waktu shalat seperti berwudhu setelah selesai bermain, berwudhu ketika mengantuk pas lagi belajar online, berwudhu setelah selesai mandi, dan berwudhu ketika mau belajar pagi hari. Namun untuk merutinkan berwudhu di luar waktu-waku shalat ini terutama era pandemi Covid-19 ini belum maksimal, dari hasil wawancara dengan responden penelitian yang mengamalkan baru $40 \%$ (Wawancara Siswa kelas III, 2021).

$\begin{array}{lrr}\text { Berwudhu } & \text { adalah } & \text { sarana } \\ \text { yang sangat } & \text { efektif } & \text { untuk } \\ \text { mengatasi kelelahan } & \text { dan }\end{array}$


kepenatan. Selain itu wudhu juga dapat memberi suntikan semangat baru bagi seseorang. Disamping itu, untuk mengembalikan keseimbangan energi yang mengalir dalam tubuh dapat dilakukan dengan wudhu. Disisi lain berwudhu juga akan memperbaiki jaringan tubuh seseorang, karena dengan wudhu dibersihkan dosa-dosa kecil atau kesalahan yang mempunyai pengaruh terhadap kondisi fsikologis dan fisik seorang muslim. sedangkan dari sudut lahir dan maknawinya, obat positif terhadap semua anggota tubuh adalah dengan berwudhu. Hal ini disebabkan wudhu dapat mengobati kerapuhan yang terdapat pada tubuh (Baduwailan dan Rasyid, 2014).

Dalam perkembangan ilmu kedokteran, anggota tubuh yang Allah perintahkan dan Rasulullah Saw contohkan untuk dibasuh ketika berwudhu adalah anggota tubuh yang yang sangat rentan terkontaminasi kuman dan tercemar oleh lingkungan sekitar. Maka wudhu secara teratur akan membersihkan debu dan kuman berbahaya lainnya dari permukaan kulit manusia dan bagian dalam. Permukaan kulit akan selalu bersih dan bagian dalam kulit berfungsi dengan baik dan normal. Hal ini karena airnya dapat mengikat jaringan rambut, kepang-kepang, darah, syaraf, dan kepang yang dekat dengan permukaan kulit sehingga setiap bagian dapat bekerja dengan dinamis dan terusmenerus (Sulaemang dkk, 2016)

Penelitian lain yang telah dilakukan sejumlah ahli pada anggota tubuh yang dibersihkan (dibasuh) denga berwudhu terdapat 493 titik akupuntur (syaraf) yang bisa digunakan untuk menyembuhkan dan mencegah penyakit. Saat berwudhu secara langsung dan tidak langsung, titiktitik itu akan tersentuh, baik melalui stimulus (dorongan) basuhan, gosokan, usapan, dan pijatan. Pijatan-pijatan ini akan diantarkan melalui titik meridian ke berbagai sel, jaringan dan system organ tubuh, sehingga akan menghasilkan regulasi system syaraf yang bekerja untuk 


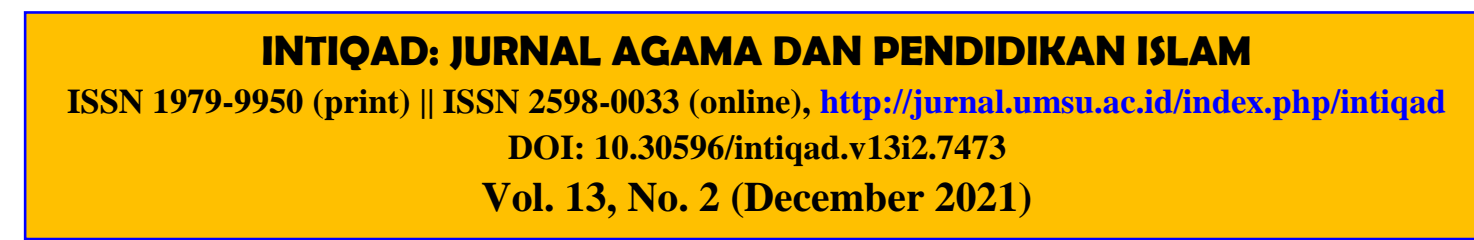

membuat keseimbangan

(homeostatis). Semua titik akupuntur yang ada pada teknik wudhu memiliki multi khasiat untuk pencegahan dan pengobatan berbagai macam penyakit (ElFikri, 2019).

Pada hakikatnya Thaharah (wudhu) akan melindungi diri, lingkungan dan masyarakat dari penularan penyakit, kelemahan dan kelumpuhan, karena thaharah mencuci anggota badan secara lahir yang setiap harinya akrab dengan debu, kuman maupun tanah yang menempel (Nurhayati dan Ramadhani, 2020).

\section{c. Merutinkan Jum'at Bersih}

Untuk membiasakan siswa ikut serta dalam menjaga kebersihan dan kesehatan dirumah terutama era pandemi Covid-19 ini setiap hari Jum'at diadakan Jum'at Bersih di MI Plus Al-Muhajirin Depok jaya. Sebelum mulai belajar siswa ikut membantu bersih-bersih di rumah terlebih dahulu, seperti menyapu, mengepel, mencuci piring, membersihkan halaman rumah dan sebagainya. Kegiatan
Jum'at bersih ini bagian dari absen pagi di hari Jum'at yang dipantau oleh wali kelas masing-masing. Jum'at bersih yang diadakan berjalan dengan baik, lancar dan setiap siswa akan mengirim foto kegiatan yang dilakukan di rumah dikirim wali kelas masing-masing sebelum mulai belajar pagi (Wawancara dan dokumentasi Siswa kelas III, 2021).

\section{d. Memotong Kuku Setiap Hari Jum'at}

Salah satu sunnah yang diajarkan dalam Islam di hari Jum'at adalah memotong kuku yang sudah panjang. Di MI Plus Al Muhajirin Depok Jaya setiap hari Jum'at ada pemeriksaan kuku siswa oleh wali kelas masingmasing. Pemeriksaan kuku oleh wali kelas setiap hari Jum'at ini sudah berjalan lama di MI plus Al Muhajirin Depok Jaya, ketika masih belajar offline / sebelum pandemi Covid-19 pemeriksaan kuku biasanya dilakukan sebelum masuk kelas / ketika berbaris di depan kelas setelah bel tanda masuk kelas berbunyi di pagi hari, 
INTIQAD: JURNAL AGAMA DAN PENDIDIKAN ISLAM

ISSN 1979-9950 (print) || ISSN 2598-0033 (online), http://jurnal.umsu.ac.id/index.php/intiqad

DOI: 10.30596/intiqad.v13i2.7473

Vol. 13, No. 2 (December 2021)

dan sekarang masih berlanjut hanya saja melalui foto yang dikirim masing-masing siswa sebelum di mulai pembelajaran pagi. Berdasarkan hasil penelitian, $90 \%$ siswa MI Plus Al Muhajirin khususnya kelas III sangat peduli dengan kebersihan kuku terutama di era pandemi Covid-19 ini (Dokumentasi dan Wawancara, Januari 2021).

Penampilan yang bersih, rapi dan indah tentu akan menciptakan citra yang baik dari orang lain, karena selain menjalin hubungan baik dengan Allah tentunya dengan sesama makhluk sosial kita juga harus menjalin hubungan baik salah satunya dengan menjaga kebersihan diri sehingga orang yang berinteraksi dengan kita tidak terganggu kenyamannya hanya karena lawan biacaranya tidak bersih.

\section{Kesimpulan}

Pengetahuan Thaharah yang dimiliki siswa akan mengarahkan mereka dalam mengamalkan thaharah. Pengetahuan thaharah sangat penting untuk pengamalan thaharah dalam kehidupan sehari-hari terutama di era pandemi COVID-19. Dengan pengetahuan thaharah, siswa akan lebih termotivasi menjaga kebersihan dan kesehatan, baik kebersihan diri maupun lingkungan khususnya di era pandemi Covid-19.

Pengamalan Thaharah di era pandemi Covid-19 salah satu solusi terbaik untuk mencegah penularan Covid-19 khususnya bagi umat muslim. Mengamalkan thaharah di era Covid-19 diibaratkan sepeti kata pepatah "sekali menyung, dua tiga pulau terlampau" karena tidak hanya jasmani yang bersih dan sehat akan tetapi dosa-dosa kecil seorang mukmin juga akan terhapus dengan pengamalan thaharah (merutinkan wudhu) juga termasuk mengamalkan sunnah yang dicontohkan oleh Rasulullah SAW.

\section{E. Daftar Pustaka}

Al-Qardhawi, Yusuf, (2004). Fiqhu at Thaharah, Penerjemah Samson Rahman, Jakarta: Pustaka AlKautsar.

Yuliana, (2020). Corona Virus Diseases; Sebuah Tinjauan Literatur. Wellness and Healthy Magazine, 2(1), 187-192. 
INTIQAD: JURNAL AGAMA DAN PENDIDIKAN ISLAM

ISSN 1979-9950 (print) || ISSN 2598-0033 (online), http://jurnal.umsu.ac.id/index.php/intiqad

DOI: 10.30596/intiqad.v13i2.7473

Vol. 13, No. 2 (December 2021)

Parwanto, (2020). Virus Corona (2019nCoV) Penyebab Covid-19. Jurnal Biomedika dan Kesehatan, 3(1), 1-2.

Nopsi, Marga. (2021). Update Corona Dunia Selasa, 27 Juli 2021: Indonesia Peringkat Pertama untuk Kasus Kematian Tertinggi. PikiranRakyatCom.

Yunus, N. \& Rezki, A. (2020). Kebijakan Pemberlakuan Lock Down Sebagai Antisipasi Penyebaran Corona Virus Covid-19. Salam: Jurnal Sosial dan Budaya Syar-i, 7(3), 277238.

Nurhayati dkk, (2015). Fiqh Ibadah. Pekan Baru: Mutiara Pesisir Sumatera.

Nurdin, (2020). THE CULTURE OF THAHARAH IN IN CORONA VIRUS PANDEMIC: An Offer to Prevent the Spread of Covid19 with Islamic Jurisprudence Approach. Madania: Jurnal Kajian Keislaman, 24(2).

Kudori, M. (2015). Implementasi Pendidikan Thaharah Pada Santri Pondok Pesantren Pancasila Kota Bengkulu, Tesis Magister Pendidikan Islam IAIN Bengkulu.

Sukmadinata, N. S. (2005). Metode Penelitian Pendidikan. Bandung: Remaja Rosdakarya.
Rustaman, \& Nuryani. (2005). Strategi Belajar Mengajar Biologi, Malang: UM Press.

Az-Zuhaili, W. (2011). Fiqih Islam Wa'adillatuhu. Terj. Abdul Hayyie al-Kattani, dkk. Cet.1 Jakarta: Gema Insani.

Qotadah, H. A. (2020). Covid-19: Prayers Performance of Medical Team Without ablution and Tayammum Based On Four Madhab Fiqh. Salam: Jurnal Sosial dan Budaya Syar-i, 7(10), 855-874.

Susanto, T., \& Sulistyorini, L. (2016). School Health Promotion: A cross-sectional study on Clean and Healthy Living Program Behavior (CHLB) among Islamic Boarding Schools in Indonesia. International Journal Of Nursing Sciences, 3, 291298.

Al-Hanafi, Hasan bin Ammar bin Ali asSyirnibali al-Mishri. (2005). Muraqi Al-Falah Syarh Matn Nur Al-Idhah. Mesir: Maktabah al-'Ashriah.

Koem, Z., \& Joseph, B., \& Sondakh, R. C. (2015). Hubungan antara Pengetahuan dan Sikap dengan Perilaku Hidup Bersih dan Sehat (PHBS) Pada Pelajar di SD Inpres Sukur Kecamatan Airmadidi Kabupaten Minahasa Utara. PHARMACON Jurnal 
INTIQAD: JURNAL AGAMA DAN PENDIDIKAN ISLAM

ISSN 1979-9950 (print) || ISSN 2598-0033 (online), http://jurnal.umsu.ac.id/index.php/intiqad DOI: 10.30596/intiqad.v13i2.7473

Vol. 13, No. 2 (December 2021)
Ilmiah Farmasi, 4(4), 23022493.

Djamaludin, D. (1995). Psikologi Islam, Yokyakarta: Pustaka pelajar.

Kusnawa, Wowo Sunaryo. (2012). Taksonomi Kognitif: Perkembangan Ragam Berfikir, Bandung: Remaja Rosdakarya.

Yasin, Q., A., F. (2012). Physical and Spritual Miracles Of Muslims' Ablution. International Journal on Quranic Reseach, 2(2).

Baduwalain, A. S \& Hishah, (2014). Berobatlah dengan Shalat dan Al-Quran, Solo: Aqwam.

Sulaemang, L., Zulkifli, M., Kuraedah, Zubaedah. (2016). Ablution and Different Kinds of
Diseases. International Journal of Sciences: Basic and Applied Research (IJSBAR), 28(3), 2303-4531.

El-Fikri, S. (2019). Sehat dengan Wudhu, Jakarta: Republika.

Nurhayati, \& Ramadhani, (2020). Pengaruh Pelaksanaan Pendidikan Agama Islam Terhadap Pengamalan Thaharah Tentang Wudhu dan Mandi Wajib pada Siswa. Jurnal Pendais, 2(2), 179-202.

Jamaluddin, (2018). Fiqh Al-Bi'ah Ramah Lingkungan; Konsep Thaharah dan Nadhafah dalam Membangun Budaya Bersih. Tribakti: Jurnal Pemikiran Islam, Jurnal: Pemikiran Keislaman, 29(2). 